\title{
The Vegetative Development of Sinningia leucotricha Hoehne (Moore) Under Different Levels of Shading
}

\author{
Lilian Keiko Unemoto ${ }^{1}$, Ricardo Tadeu de Faria ${ }^{1}$, Adriane Marinho de Assis ${ }^{1}$ and Deonisio \\ Destro $^{1^{*}}$ \\ ${ }^{1}$ Departamento de Agronomia; Universidade Estadual de Londrina; C. P. 6001; 86051-990; Londrina - PR - Brasil
}

\begin{abstract}
This work aimed at the assessment of the influence of different levels of shading in the development of (Sinningia leucotricha Hoehne (Moore). Tuberous roots of $2.3 \pm 0.3 \mathrm{~cm}$ in diameter were used as vegetative material. The cultivation was performed in plastic vases and gross sand as substrate, and conditioned in sheltered nurseries protected by black polypropylene nets in the followings percentages: 0\% (under full sunlight), 50, 60, and 70\%. Sheltered nurseries with 60 or $70 \%$ of shading presented the highest vegetative development for Brazilian edelweiss. The cultivation of this species under full sunlight is not recommended.
\end{abstract}

Key words: Gesneriaceae, floriculture, greenhouse

\section{INTRODUCTION}

The Brazilian edelweiss (Sinningia leucotricha Hoehne (Moore) is a plant native from Parana state, Brazil, and belongs to the Gesneriaceae family, which is comprised by approximately 150 genera and 3,000 species (Chautems, 2003).

It is an herbaceous plant with leaves of dense pilosity presenting a woolly aspect of silver colouration. It has a red campanulate inflorescence. Its root system is comprised by a tuberous root and secondary roots that are entitled to the fixation and the plant's nutrition (Iuchi, 1994).

Due to the beauty of its flowers and silver leaves, this plant has been a target of uncontrolled extraction and commercialization, putting it, therefore, in danger of extinction. Brazilian edelweiss is a plant extracted from its habitat under different growing phases; however, the larger the tuberous root, the higher is its value in the market. In the face of the problems mentioned, there is a need studies which would assist in the commercialization of this Brazilian species that presents a huge ornamental potential. Many studies have been accomplished to understand and to preserve the native species (Souza et al., 2001; Droste et al., 2005; Unemoto et al., 2006; Lone et al., 2008; Assis et al., 2009).

According to Blank et al. (2003), the production of seedlings of many ornamental species either native or not are not totally established, requiring more studies regarding the type of substrate, shading needs, size of recipients among others. According to Reid et al. (1991), each species has its own exigencies for its development.

\footnotetext{
* Author for correspondence: ddestro@uel.br
} 
Factors such light, water, temperature, and edaphic conditions are some of the environment elements that interfere in the plant's development. The light energy is fundamental for the plant's development, and the variations regarding its qualities, quantities, presence or absence strongly influence the type of development the plant will present (Poggiani et al., 1992). According to Paiva et al. (2003) different light intensities can promote alterations in the structural organization of the leaves.

Toumey and Korstian (1962) affirm that the light act directly in the photosynthesis. The light influence in the photosynthesis varies in function to its intensity, duration, and quality; and it might be prejudicial when out of the levels required by the plant. The luminance influences directly the process of germination, growth, fructification, propagation as well as the formation of development of structures such as bulbs, tubercles, and other storage organs.

The plants have developed several mechanisms for getting information regarding the environment brightness in addition to the energy capture for photosynthesis, therefore, maximizing the light acquisition and avoiding disadvantageous environmental conditions. These information are used for coordinating the changes in the growth and vegetal developments or as a signal inciting the expression of phenotypical plasticity, present in all plants, for optimizing the acquisition of resources or tolerance to less advantageous conditions (Reid et al., 1991).

The plant's adaptation to the bright environment depend on adjustment of its photosynthetic machinery in a way that the environmental luminosity be used in the most efficient manner, being reflected in the plant's global growth. Thus, the growth efficiency may be related to the ability of the plantlets adaptation and to the conditions of luminous intensity of the environment. Frequently, the analyses of growth are used for studying the degree of tolerance of several species to the shading (Fanti and Perez, 2003; Vilela and Ravetta, 2000). According to Válio (2003), shading affects the plant growth and development at all levels of organization.

The reduction of the sunlight upon the plants may be done through the nets, which also contributes for reducing the temperature on the plant once exposed directly. For example if the leaves are directly exposed to the sun, there could be an increase of temperature up to $15^{\circ} \mathrm{C}$ (Kämpf, 2000).
According to Brissete et al. (1991), the reduction of the sun radiation by the shading nets may also reduce the temperature inside the green house up to $5^{\circ} \mathrm{C}$.

Due to the fact that it is a native species still under the extraction phase, there are few studies available regarding the Brazilian edelweiss. However, there were no information regarding the shading conditions for cultivating this plant as parameters for further discussions.

This work aimed at the assessment of the influence of different levels of shading in the Brazilian edelweiss' vegetative development.

\section{MATERIAL AND METHODS}

The study was carried out during June and December 2006. The experimental delineation used was the completely randomized blocks, with 15 repetitions per treatment, and each plot comprised by a pot with a plant.

Tuberous roots with approximately $2.3 \pm 0.3 \mathrm{~cm}$ diameter were used as vegetative material. The substrate was gross sand, which was placed on the bottom of the vase with a layer of pebble for a good drainage.

Black plastic vases with $(10.5 \mathrm{~cm}$ height and 12.5 $\mathrm{cm}$ diameter), which had four holes on the lower part were used. The vases were kept in shelter nurseries and protected with polypropylene net of black colour, presenting the following percentages: $0 \%$ (without shading in the green house), 50, 60, and $70 \%$ of retention of the solar radiation flow.

Fertirrigation was performed for $30 \mathrm{~min}$, there were with the NPK 6-6-8 (3 mL.L $\left.{ }^{-1}\right)(20 \mathrm{~mL}$ per vase every three days). The average once temperature and relative humidity of the air during the assay's period are show in the Table 1. Six months after the commencement of the experiment, the following characteristics: height of the aerial part $(\mathrm{cm})$, the length of the largest root $(\mathrm{cm})$, number of leaves, number of buds, fresh and dry masses of the aerial part $(\mathrm{g})$, fresh mass of the tuberous root $(\mathrm{g})$, and the growth of the tuberous root $(\mathrm{cm})$ were assessed. The last parameter was assessed through the difference among the initial and the final diameters of the tuberous roots.

A paquimeter was used for measuring the length of the largest root and the diameter of the tuberous root. To determine the dry mass of the aerial part, 
the samples were dried at $65^{\circ} \mathrm{C}$ in air oven for 48 h. The data were submitted to analysis of variance, and complemented by the test of averages of
Tukey at $5 \%$ of probability and tests of regression (Banzato and Kronka, 1995).

Table 1 - Mean values of temperature and relative humidity of the nurseries under different conditions of luminosity between June and December 2006, Londrina, Parana State, Brazil.

\begin{tabular}{ccc}
\hline Shading Levels & Mean temperature $\left({ }^{\circ} \mathbf{C}\right)$ & Relative humidity (\%) \\
\hline $0 \%$ (full sunlight) & 27.5 & 52.2 \\
$50 \%$ & 26.5 & 54.1 \\
$60 \%$ & 25.8 & 55.3 \\
$70 \%$ & 26.2 & 54.5 \\
\hline
\end{tabular}

\section{RESULTS AND DISCUSSION}

Table 2 shows the mean values regarding the following variables: height of the aerial part, length of the largest root, number of leaves, and number of buds of Brazilian edelweiss.

The plants of Brazilian edelweiss presented higher height of the aerial part when cultivated under shading net of $70 \%$ of luminosity retention, and were statistically better than plants cultivated under full sunlight and those under shading net of 50 and $60 \%$ of luminosity retention, (the last two did not present any difference among themselves). Regarding the cultivation of gloxinia (Gesneriaceae), Longhi and Tombolato (1995) suggested environment under controlled luminosity and with layers of plastic films and shading nets of $50-60 \%$ of luminosity retention.

Morais et al. (2003) found that shading induced a more expressive effect on the height in coffee (Coffea arabica). In studies with Cyclamen persicum, Villegas et al (2006) found the best results for the growth under $50 \%$ of shading. Zanella et al (2006) obtained the best values for the stem's length of passion fruit (Passiflora edulis) with $70 \%$ of shade and the lowest mean in plants cultivated under the fully sunlight. Lima Junior et al. (2005) found smaller growth means in plants of Cupania vernalis when cultivated under full sunlight. According to Muroya et al. (1997), the height is an excellent growth parameter as the species have different response pattern according to their adaptive ability to the variation of the light intensity.

Concerning the length of the largest root, the number of leaves, and the number of buds, there were no statistical differences in the different conditions of shading studied. According to Iuchi
(1994), the Brazilian edelweiss is a plant of determined growth with a fixed number of leaves. The effects of luminosity and photoperiod could interfere only in the increase of the number of leaves through bud promotion, therefore increasing the number of stems per tuberous root, a fact not observed in this work.

Table 3 shows the mean values for the following characteristics: fresh mass of the aerial part, fresh mass of the tuberous root, and the growth (diameter) of the tuberous root of the Brazilian edelweiss cultivated under different shading levels.

This showed a higher accumulation of fresh mass of the aerial part in plants cultivated under 60 and $70 \%$ of retention in relation to the plants cultivated under full sunlight and $50 \%$ of retention.

The results for dry mass of the aerial part also indicated a higher accumulation of mass of the plants cultivated under $70 \%$ of shading in relation to those under $50 \%$ of retention and full sunlight. Such data indicated that the highest plants were found mostly in shaded environments, showed more vigorous with the highest means of fresh and dry masses in comparison to the plants cultivated under the full sunlight. In studies with passion fruit plants (Passiflora edulis), Kluge (1998) and Silva et al. (2006) observed that plants cultivated under lower luminous intensities presented longer branches, but also presented reduction in dry mass and a lesser accumulation of nutrients - a fact attributed to etiolation due to the conditions of the reduced shading on these plants.

No significative difference were observed in the dry mass among the 50,60, and $70 \%$ of shading. Lima Junior et al. (2005) found more accumulation of total dry mass in plants of Cupania vernalis cultivated under $50 \%$ shading in 
relation to the plants cultivated under full sunlight. Naves et al. (1993), studying the productions of seedlings of Sesbania sesban Merrill (Leguminosae), under four levels of luminosity
(30, 50, 70, and 100\%), observed that S. sesban presented the best accumulation of total dry mass and the largest diameter of stem when cultivated under $100 \%$ of luminosity.

Table 2 - Mean of the treatments concerning the assessments of the aerial part height, the length of the largest root, number of leaves, and number of buds of Sinningia leucotricha under different conditions of shading levels six months after the commencement of the experiment. UEL, Londrina, Parana State, Brazil.

\begin{tabular}{|c|c|c|c|c|}
\hline $\begin{array}{l}\text { Shading levels } \\
(\%)\end{array}$ & $\begin{array}{l}\text { Aerial part height } \\
\text { (cm) }\end{array}$ & $\begin{array}{l}\text { Length of the largest root } \\
(\mathrm{cm})\end{array}$ & $\begin{array}{l}\text { Number of } \\
\text { leaves }^{(2)}\end{array}$ & $\begin{array}{c}\text { Number of } \\
\text { buds }^{(2)}\end{array}$ \\
\hline 0 (full sunlight) & $1.34 \mathrm{~b}^{(1)}$ & $12.15 \mathrm{a}$ & $3.10 \mathrm{a}$ & $1.29 \mathrm{a}$ \\
\hline 50 & $1.93 \mathrm{~b}$ & $13.87 \mathrm{a}$ & $3.39 \mathrm{a}$ & $1.38 \mathrm{a}$ \\
\hline 60 & $2.36 \mathrm{~b}$ & $13.89 \mathrm{a}$ & $3.25 \mathrm{a}$ & $1.25 \mathrm{a}$ \\
\hline 70 & $3.93 \mathrm{a}$ & $14.92 \mathrm{a}$ & $2.73 \mathrm{a}$ & $1.09 \mathrm{a}$ \\
\hline $\mathrm{cv}(\%)$ & 22.34 & 22.24 & 16.86 & 19.21 \\
\hline
\end{tabular}

The results for fresh mass of tuberous root that plants cultivated under $60 \%$ of retention had a mass accumulation better to those cultivated under full sunlight. However, there was no significant differences among the plants cultivated under 50, 60 , and $70 \%$ of shading. Wiebel et al. (1994) observed that seedlings grown in 20 or 50\% shade accumulated significantly more dry weight than seedlings grown in $80 \%$ shade during the 2-year study period.

It was observed that the growth of the diameter of tuberous root was higher in plants cultivated under $70 \%$ of shading than in those cultivated under full sunlight. Nevertheless, there was a significant difference among the treatment that exposed the plants to full sunlight and to $70 \%$ of shading, which presented a better development of the tuberous root in plants cultivated under $70 \%$ of shading. According to Kerbauy (2004), environmental factors such as luminosity, temperature, and photoperiod influence the formation and growth of storing organs such as the Brazilian edelweiss's tuberous root, whose apical portion - having the buds - need not to be kept underground.

Table 3 - Mean of the treatment regarding the assessments of fresh mass of the aerial part, dry mass of the aerial part, fresh mass of the tuberous root, and the growth in diameter of Brazilian edelweiss six months after the commencement of experiment. UEL, Londrina, Parana State, Brazil

\begin{tabular}{ccccc}
\hline Shading levels (\%) & $\begin{array}{c}\text { Fresh mass of } \\
\text { aerial part }(\mathbf{g})\end{array}$ & $\begin{array}{c}\text { Dry mass of } \\
\text { aerial part }(\mathbf{g})\end{array}$ & $\begin{array}{c}\text { Fresh mass of } \\
\text { tuberous root }(\mathbf{g})\end{array}$ & $\begin{array}{c}\text { Growth in diameter of } \\
\text { the tuberous root }(\mathbf{c m})\end{array}$ \\
\hline 0 (full sunlight) & $0.95 \mathrm{c}^{(1)}$ & $0.16 \mathrm{c}$ & $5.11 \mathrm{~b}$ & $0.35 \mathrm{~b}$ \\
50 & $1.81 \mathrm{~b}$ & $0.23 \mathrm{bc}$ & $6.46 \mathrm{ab}$ & $0.48 \mathrm{ab}$ \\
60 & $2.89 \mathrm{a}$ & $0.35 \mathrm{ab}$ & $8.23 \mathrm{a}$ & $0.58 \mathrm{ab}$ \\
70 & $3.35 \mathrm{a}$ & $0.41 \mathrm{a}$ & $7.13 \mathrm{ab}$ & $0.71 \mathrm{a}$ \\
\hline $\mathrm{cv}(\%)$ & 36.06 & 35.24 & 37.82 & 29.25 \\
\hline
\end{tabular}


According to Barber and Anderson (1992), the lowest growth of seedlings in response to the absence of light retention could be explained by the fact that the excess of light, above the use capacity via photosynthesis, might result in a stress condition, known as photoinhibition photosynthesis. Rocha (2002) affirm that the reduction of the efficiency of this process also diminishes consequently the mass of the plants. Besides the reduction of photosynthesis under excessive solar radiation, the growth can be jeopardized by the increase of the respiratory rate, decreasing the net photosynthesis and consequently the gain of biomass by the plants. The proportional increase of the means - obtained in relation to the increase of levels of retention of luminosity in the cultivation of Brazilian edelweiss - was noticed through regression tests for the following variables: fresh and dry masses and growth of the tuberous root (Figs. 1, 2, and 3). Generally speaking, the results of this work have shown that the exposition of the plant to full sunlight $(0 \%)$ was not favourable to most of the characteristics assessed such as the height of the aerial part, fresh and dry mass of the aerial part, fresh mass of the tuberous root and the growth of the tuberous root (diameter). The sheltered nurseries with 60 or $70 \%$ of shading were most suitable for the Brazilian edelweiss vegetative development. The cultivation of this species under full sunlight is not recommended.

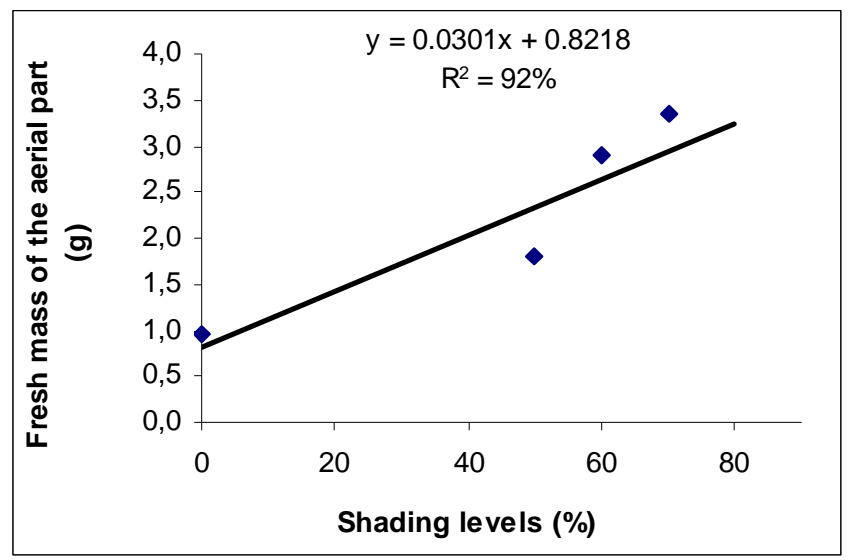

Figure 1 - Fresh mass of the aerial part of Brazilian edelweiss cultivated under different shading levels, six months after the commencement of experiment.

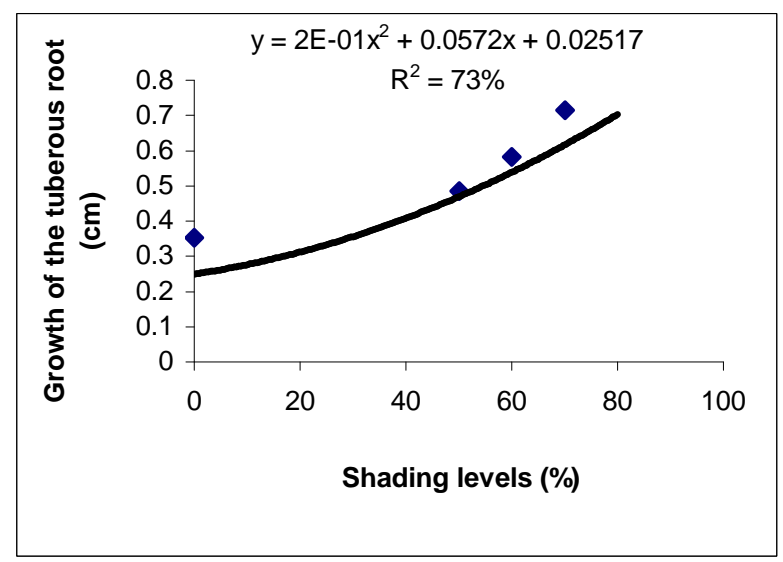

Figure 2 - Growth of the tuberous root of Brazilian edelweiss cultivated under different shading levels, six months after the commencement of experiment. 


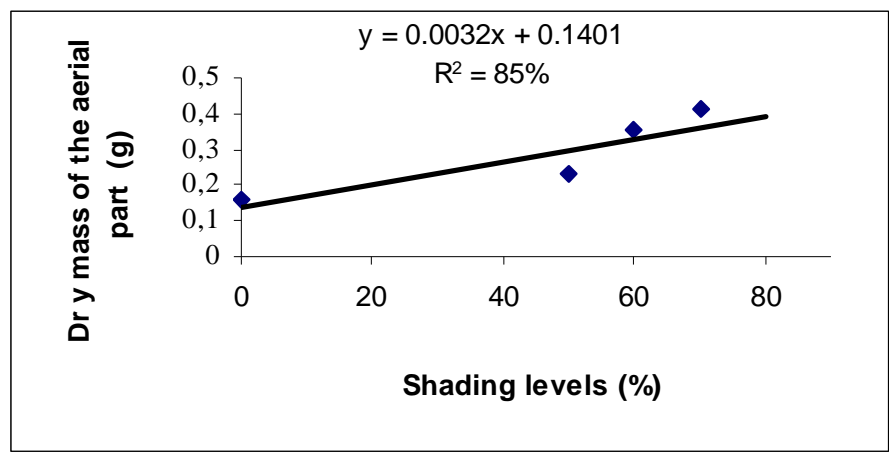

Figure 3 - Dry mass of the aerial part of Brazilian edelweiss cultivated under different shading levels, six months after the commencement of experiment.

\section{RESUMO}

A rainha-do-abismo (Sinningia leucotricha Hoehne (Moore) é uma planta nativa do Estado do Paraná, se destaca pela beleza de suas folhas de aspecto prateado. Este trabalho teve como objetivo avaliar a influência de diferentes níveis de sombreamento no desenvolvimento de plantas de rainha-do-abismo. Para o experimento foram utilizadas como material vegetativo raízes tuberosas com 2,3 $\pm 0,3 \mathrm{~cm}$ de diâmetro. $\mathrm{O}$ cultivo foi realizado em vasos plásticos e areia grossa como substrato, que foram acondicionados em viveiros protegidos com tela de polipropileno de coloração preta, nas seguintes porcentagens: $0 \%$ (a pleno sol) $50 \%, 60 \%$ e $70 \%$. Viveiros protegidos com $60 \%$ ou $70 \%$ de sombreamento foram os que proporcionaram maior desenvolvimento vegetativo de rainha-do-abismo. O cultivo desta espécie a pleno sol não é recomendado.

\section{REFERENCES}

Assis, A. M.; Faria, R. T.; Unemoto, L. K. and Colombo, L. A. (2008). Cultivo de Oncidium baueri Lindley (Orchidaceae) em substratos a base de coco. Ciência $e$ Agrotecnologia. 32, 981-985.

Banzatto, D. A. and Kronka, S. N. (1995), Experimentação agrícola. Jaboticabal: Funep.

Barber, J. and Anderson, B. (1992), Too much of a good thing: light can be bad for photosynthesis. Trends in Biochemical Sciences, Amsterdam, 17, 6166.
Blank, M. F. A.; Carvalho Filho, J. L. S.; Blank, A. F. and Santos Neto, A. L. (2003), Efeitos do substrato e luminosidade na emergência e desenvolvimento de mudas de jasmim-laranja (Murraya exotica 1.). Revista Ciência Agronômica, 34, 5- 12.

Brissete, J. C.; Barnett, T. J. and Landis, T. D. (1991), Container Seedlings. In- Forest regeneration manual Eds. Duryea, M. L.; Dougherty, P. M. Netherlands: Kluwer Academic Publishers, pp. 117- 141.

Chautems, A. (2003), Gênero Sinningia. In- Flora Fanerogâmica do Estado de São Paulo, ed. Wanderley, M. G. L.; Shepherd, G. J.; GIuliettie, A. M. and Melhem, T. S. São Paulo: Fapesp/ Rima, pp. 90-100.

Droste, A.; Silva, A. M.; Matos, A. V. and Almeida, J. W. (2005). In Vitro Culture of Vriesea gigantea and Vriesea philippocoburgii: Two Vulnerable Bromeliads Native to Southern Brazil. Braz. Arch. Biol. Technol. 48, pp. 717 - 722

Fanti, S. C. and Perez, S. C. J. G. A. (2003), Influência do sombreamento artificial e da adubação química na produção de mudas de Adenanthera pavonina L. Ciência Florestal, 13, 49-56.

Iuchi, V. L. (1994), Morfologia, biologia floral, propagação e crescimento de "rainha-do-abismo" Sinningia leucotricha (Hoehne) Moore. Doctor Thesis Viçosa Federal University, Viçosa, Brazil.

Kämpf, A. N. (2000), Produção comercial de plantas ornamentais. Guaíba: Agropecuária, 254p.

Kerbauy, G. B. (2004). Fisiologia Vegetal. Guanabara Koogan, Rio de Janeiro 452p.

Kluge, R. A. (1998), Maracujazeiro (Passiflora sp.). InEcofisiologia de fruteiras tropicais, coor. Castro, P. R. C. and Kluge, R. A. Nobel, São Paulo, pp. 32-47.

Lima Junior, E. C.; Alvarenga, A. A.; Vieira, E. M. C. C. V. and Oliveira, H. M. (2005), Trocas gasosas, características das folhas e crescimento de plantas jovens de Cupania vernalis Camb. submetidas a 
diferentes níveis de luminosidade. Ciência Rural, 35, pp.1092- 1097.

Lone, A. B.; Takahashi, L. S. A.; Faria, R. T.; Unemoto, L. K. (2007). Germinação de Melocactus bahiensis (Cactaceae) em diferentes substratos e temperaturas. Scientia Agrária. 8, 365-369.

Longhi, A. A. and Tombolato, A. F. C. (1995), Gloxínia (Comunicado técnico), Cati: Campinas, pp. 1- 5.

Morais, H.; Marur, C. J.; Caramori, P. H.; Ribeiro, A. M. A. and Gomes, J. C. (2003), Características fisiológicas e de crescimento de cafeeiro sombreado com guandu e cultivado a pleno sol. Pesquisa Agropecuária Brasileira, 38, pp. 1131-1137.

Muroya, K.; Varela, V. P. and Campos, M. A. A. (1997), Análise de crescimento de mudas de jacareúba (Calophyllum angulare - Guttiferae) cultivadas em condições de viveiro. Acta Amazonica, 27, pp. 197-212.

Naves, L. V.; Alvarenga, A. A. and Oliveira, L. E. M. (1993), Concentrações de clorofilas foliares de mudas de três espécies florestais submetidas a diferentes níveis de radiação fotossinteticamente ativa. Revista Brasileira de Fisiologia Vegetal, 5, p. 96.

Paiva, E. A. S. P.; Isaias, R. M. S.; Vale, F. H. A. and Queiroz, C. G. S. (2003). The influence of light intensity on anatomical structure and pigment contents of Tradescantia pallida (Rose) Hunt. cv. purpurea Boom (Commelinaceae) leaves. Braz. Arch. Biol. Technol. 46 , pp. 617- 624.

Poggiani, F.; Bruni, S. and Barbosa, E. S. Q. Efeito do sombreamento sobre o crescimento das mudas de três espécies florestais. Revista do Instituto Florestal de São Paulo, 4, pp. 564-569.

Reid, D. M.; Beall, F. D. and Pharis, R. P. (1991), Environmental Cues in Plant Growth and Development. In- Plant Physiology, ed. STEWARD, F. C. Academic Press Inc, San Diego. pp. 65-181.

Rocha, P. K. (2002), Desenvolvimento de bromélias cultivadas em ambientes protegidos com diferentes alturas e níveis de sombreamento. Dissertation, Escola Superior de Agricultura Luiz de Queiroz, Piracicaba, Brazil.

Silva, M. L. S.; Viana, A. E. S.; José, A. R. S.; Amaral, C. L. F.; Matsumoto, S. N. and Pelacani, C. R. (2006), Desenvolvimento de mudas de maracujazeiro (Passiflora edulis Sims f. flavicarpa Deg.) sob diferentes níveis de sombreamento. Acta Scientiarum, 28, pp. 513-521.

Souza, L. A.; Moscheta, I. S.; Mourão, K. S. M. and Silvério, A. (2001). Morphology and anatomy of the flowers of Trichilia catigua A. Juss., T. elegans A. Juss. and T. pallida Sw. (Meliaceae). Braz. Arch. Biol. Technol. 44, 383 - 394.

Toumey, J. W. and Korstian, C. P. (1962), Foundations of silviculture upon on ecological basis. Jhon Wiley, New York, pp. 370- 390.

Unemoto, L. K.; Faria, R. T.; Meneguce, B. and Assis, A. M. (2006). Estabelecimento de um protocolo para a propagação in vitro de rainha-doabismo, Sinningia leucotricha (Hoehne) Moore(Gesneriaceae). Acta Scientiarum Agronomy. 28, pp. 503-506.

Válio, I. F. M. (2003). Seedling growth of understorey species of a Southeast Brazilian tropical forest Braz. Arch. Biol. Technol. 46, pp. 697-703.

Vilela, A. E. and Ravetta, D.A. (2000), The effect of radiation on seedling growth and physiology in four species of Proposis L.(Mimosaceae). Journal of Arid Environmental, 44, pp.415-423.

Villegas, E., Pérez, M. and Lao, M. T. (2006). Influence of lighting levels by shading cloths on cyclamen persicum quality. Acta Horticulture. (ISHS) 711, 145-150.

Wiebel, J.; Chacko, E. K.; Downton, W. J.; Ludders, P. (1994), Influence of irradiance on photosynthesis, morphology and growth of mangosteen (Garcinia mangostana L.) seedlings.Tree Physiology,14, pp. 263- 274.

Zanella, F.; Soncela, R. and Lima, A. L. S. (2006), Formação de mudas de maracujazeiro "amarelo" sob níveis de sombreamento em Ji-Paraná/ Ro. Ciência Agrotecnológica, 30, pp. 880-884. 